\title{
8 Concluding Remarks
}

Moses Dobruska's Philosophie sociale must be seen within the troubled context of the French Revolution. It is an age of intense transformations, of febrile activism, in which social theories born out of the Enlightenment fight their way into real life. During such a period of upheaval, intellectuals were compelled to work at full steam in order to keep pace with the political arena.

Today we know that from this period of transformation also comes the first formulation of the term "sociology". I have already mentioned above the intuition of Sieyès, who lists "sociologie" within a synoptic table devoted to society and social organization. ${ }^{445}$ His manuscript having remained unpublished for two-centuries, Sieyès' coinage of the word didn't have any direct impact on later studies. Such an early emergence of the idea of sociology, however, is quite interesting, especially considering the fact that Sieyès is the author of one the most influential texts of the French Revolution. His Qu'est-ce que est le tiers état?, published in 1789 , had an enormous impact in voicing the vision of a new social order. ${ }^{446}$

In some respects, the case of the forgotten sociologie of Sieyès and of the conceptual innovations of Dobruska that were submerged by his tragic end, share some affinities.

In both circumstances, the intense power of innovation in social theories that characterizes the late eighteenth century has remained buried under the more vociferous and less troubled nineteenth century scholarship. When asked what he did during the Terror, Sieyès laconically answered "J'ai vécu", ${ }^{447}$ a healthy albeit modest goal Dobruska was unable to attain.

At first reading, the intellectual pedigree of the Philosophie Sociale seems easily ascertained. Hobbes, Montesquieu, Locke, Rousseau, Kant - Dobruska repeatedly quotes some of the most influential thinkers of the great age of Enlightenment. Instead of mentioning a vast array of men of learning, he prefers to focus on big names, and spares no effort in showing that he can match the most revered protagonists of seventeenth- and eighteenth-century social philosophy.

In some crucial points, Dobruska's social theories are modeled on his predecessors. From Hobbes and Rousseau, he adopts the idea of a social contract;

445 See above, 1. 2.

446 Emmanuel Joseph Sieyès, Qu'est-ce que est le tiers état? [s.l. 1789].

447 Kurt Röttgers, Kritik der kulinarischen Vernunft. Ein Menü der Sinne nach Kant (Bielefeld: Transcript, 2009), William H. Sewell, A Rhetoric of Bourgeois Revolution the Abbé Sieyès and What is the Third Estate? (Durham: Duke University Press, 1994), 19.

Ә Open Access. (C) 2022 Silvana Greco, published by De Gruyter. (c) BY This work is licensed under the Creative Commons Attribution 4.0 International License.

https://doi.org/10.1515/9783110758825-008 
his emphasis on education owes much to Montesquieu; the methodological foundations of his Philosophie sociale draw on Kant, and his idea of freedom is influenced by Locke, although Dobruska's approach is in some ways very different from that of his great English predecessor.

A more in-depth reading of the Philosophie sociale, however, leads one to rethink the hasty reading described above. It is neither a hodgepodge of the opinions of others, nor, as has recently been said, a simple draft of a Constitution, lacking originality.

In the present study, I have tried to give this "second chance" to the Philosophie sociale. The reader will judge whether it was worth it and whether, as I believe, this review casts a new light on a phase still little studied, but fundamental, for the history of social thought in the modern age.

In order to understand the Philosophie sociale, and to insert it correctly in its historical context, it is first necessary to go through the life of Moses Dobruska, so troubled and full of transformations.

After a general introduction on my work and its aims, in the second chapter I have thus sketched the biography of our author, which extends across various countries, during the second half of the eighteenth century. We first went to Brno in Moravia under the Habsburg dynasty, where Moses was born into a Jewish family that had risen to considerable wealth. As Gershom Scholem's research has shown, his mother, Schöndl, and probably also his father, Solomon, were followers of the Sabbatian sect, and therefore had a position in contrast to rabbinical orthodoxy. We followed Moses to Prague, where he converted to Catholicism in, and then to Vienna. It is here that his considerable economic and social rise takes place. Made noble by Maria Theresa as a reward for conversion, Moses entered the imperial court under the new name of Franz Thomas von Schönfeld, until he became a valued entrepreneur and supplier to the Habsburg army. In 1792 we saw a turning point in his life. Perhaps due to problems with the court of Leopold II, who became emperor after the death of his brother Joseph II, Moses left Vienna for Strasbourg, where he began engaging in political activity within the ranks of the Jacobins, under the name of Sigismond-Gottlob (later Junius) Frey. From Strasbourg he arrived in Paris, and at the end of June 1793 he published the Philosophie sociale. His revolutionary season, however, only lasted a few months. Charged with treason, he was arrested and executed on April 5, 1794.

The third chapter brought us into contact with the main topic of my work, namely an in-depth examination of the Philosophie sociale. Starting from the title, the book makes us immediately enter into the reflection on social reality, and proposes many research questions and reflections, to which Dobruska intends to respond with the elaboration of articulate theories. 
As we have seen, these research questions are those that sociologists and social philosophers still ask themselves today: what are the needs of men, how and why do men live in society, what do they get out of it? And again, what impact do laws have on the behavior and customs of individuals, how social bonds are defined; what is the morality of the individual and what is the morality of the State, what is selfishness, and what is reciprocity? What may not work in society, and what prevents proper social organization? A question crowns all previous ones. How does man achieve happiness? Which social system is best suited to achieving universal happiness?

The answers Dobruska gives to these questions occupy the central part of my work. The fourth chapter deals with man and society, while the fifth and the sixth chapters deal, respectively, with political systems and structures - democracy, aristocracy and monarchy - and the ultimate goal of future democracy, namely the happiness of citizens.

In the course of the analysis, I have focused on two dimensions of the Philosophie sociale, which are linked to each other. I have defined the first component of Dobruska's thought as a sociological approach, which observes human behavior and social interaction from an objective, purposely scientific perspective. By choosing such a scientific approach, Moses Dobruska anticipated some important issues, concepts, and theories that were later developed by the founding fathers of sociology and even by the sociologists of the 20th century.

Dobruska's new founded discipline has three core aims.

The first aim of the Philosophie sociale is to assess the old social order, pulling out all of its "negative outcomes" for the majority of the population. Dobruska describes the "disorganizing” political and social phenomena such as tyranny, privileges, and the power abuses of aristocracy and clergy, that caused the Ancien Régime to collapse.

The second aim of Dobruska's work is to understand the society of the late eighteenth century, and to explain the motivations of individuals and their behaviors. He wants to analyze both society as a collective structure and through lone individuals - their motivation, desires, ambitions, morality, and behaviors.

The third aim is to delineate social rules and principles, based on the observation of human nature and human experience, and not on some "metaphysical or religious principles". The principles, rules and social institutions we encounter in the Philosophie sociale are related to seventeen different topics: human beings; social contracts; principles, duties and selfishness; individual morality; morality and immorality of society; the right of the strongest and the right of trickery; laws, power, legislative bodies; the sovereign; public contributions; government; liberty; equality; education; pains and offense; unity of interests; democracy, aristocracy, monarchy, and representative democracy. Already 
this sketchy list shows Dobruska's ambitious idea of an all-encompassing categorization of society, and his painstaking effort to base constitutional theory on social dynamic.

In other words, Moses Dobruska aims at developing an analytical and descriptive science of society, which later on became known as "sociology".

Given such a theoretical frame, we can appreciate how Moses Dobruska is the first to formulate concepts that have had a very important role in the following sociological thinking.

The first of these concepts is social disorganization (désorganisation sociale in Dobruska's French text).

The second concept, which derives from the first and completes it in a positive sense, is that of social organization and social cohesion. In his Philosophie sociale Moses Dobruska aims at defining principles, social rules, and norms for the construction of a new democratic society. According to his social-philosophical thought and to his empirical, sociological understanding of individuals living in a society, he asserts the importance of morality, of reciprocity in social interaction, and of the overcoming of selfishness. As a result, he tackles one of the most important issues of sociological debate since its early stage: the topic of social cohesion. His treatment of this topic intends to answer a question that has played a major role in sociology from its conception until today: how is society possible and how can it perpetuate itself? While the founding fathers of sociology ${ }^{448}$ and later sociologists have answered this question very differently, according to their different theoretical perspectives, ${ }^{449}$ Moses Dobruska must be considered one of first inquirers of social cohesion as a prerequisite to social organization.

The third innovative concept is that of social treasure (trésor social, soziales Tresor in the German draft). According to Dobruska, the social treasure consists in "all the means of culture and its instruments, i.e. the material and intellectual appetitive faculty". ${ }^{450}$ This social treasure can only be developed within the society, and it belongs to the community, i.e. to the social self. After Dobruska, and most probably on the basis of his work, we find mention of the social treasure in a patriotic poem by Paul-Ėmile Raboteau, published in 1830,

448 See, for example, Emile Durkheim, De la division du travail social. Étude sur l'organisation des sociétés supérieures, Paris: Félix Alcan, 1893.

449 Noah F. Friedkin, “Social Cohesion,” Annual Review of Sociology 30 (2004), 409-425; Caroline Guibet Lafaye, "Modèles de la cohésion sociale”, European Journal of Sociology / Archives Européennes de Sociologie / Europäisches Archiv für Soziologie 50 (2009) 3, 389-427; Paul Spicker, “Cohesion, Exclusion and Social Quality,” The International Journal of Social Quality 4 (2014): 95-107.

450 Dobruska, Philosophie sociale, 150. 
and in the Harmonies économiques by Fréderic Bastiat. ${ }^{451}$ Later on, it was used by Ferdinand de Saussure in linguistics, and by no less writer than Marcel Proust. ${ }^{452}$ As is well known, Pierre Bourdieu has stressed how culture, in its different forms, constitutes a "treasure", which he termed "cultural capital". Bourdieu speaks of a threefold capital: i) "embodied state" - i.e. inherited and acquired properties in one's self; i) “objectified cultural goods"; iii) "institutionalized cultural entitlement". ${ }^{453}$ While Dobruska's theory of a social treasure is less articulated than Bourdieu's cultural capital, it nevertheless posits the core idea of a cultural asset, socially determined, that can be deployed individually.

The fourth concept is that of a social ego or social self (moi social). Moses Dobruska distinguishes between an "individual self" and a "social self". According to him, the individual self that exists in the state of nature is transformed into a social self in the state of culture, that is, within the fabric of society. ${ }^{454}$ In his Du contrat social, Jean-Jacques Rousseau had already spoken of a moi commun as a kind of collective personality, expressing a rational consensus (volonté générale) of all individuals within a community. ${ }^{455}$ Dobruska transforms the Rousseauian "moi commun" into a sociological category by eliminating its voluntarist overtones, while stressing the social interaction and solidarity implicit in the distinction between the individual self and the social one.

451 Paul-Émile Raboteau, Poème (Paris: Chez l'Auteur, 1830), 77: [au trésor social chacun doit ses tributs]; Fréderic Bastiat, Harmonies économiques, (Bruxelles: Meline, Cans et Compagnie, 1850): [Et remarquez que Robinson [Crusoe] portait avec lui dans la solitude un autre trésor social mille fois plus précieux et que les flots ne pouvaient engloutir: je veux parler de ses idées, de ses souvenirs, de son expérience, de son langage même, sans lequel, il n'aurait pus s'entretenir avec lui-même, c'est-à-dire penser]. Cf. Silvana Greco, "Heresy, Apostasy, and the Beginnings of Social Philosophy. Moses Dobruska reconsidered,” Materia giudaica 20-21 (2015-2016), 454.

452 Ferdinand de Saussure, Cours de linguistique Générale (Paris 1972 (I ed. 1913), 30; Marcel Proust, A la recherche du temps perdu, vol. 7, Le côté de Guermantes (Paris: Gallimard, 1919), 221-222: [La nubilité plus accentuée s'était marquée quand Albertine, parlant d'une jeune fille qui avait mauvaise façon, avait dit: 'On ne peut même pas distinguer si elle est jolie, elle a un pied de rouge sur la figure.' Enfin, quoique jeune fille encore, elle prenait déjà des façons de femme de son milieu et de son rang en disant, si quelqu'un faisait des grimaces: 'Je ne peux pas le voir parce que j'ai envie d'en faire aussi', ou si on s'amusait à des imitations: 'Le plus drôle, quand vous la contrefaites, c'est que vous lui ressemblez.' Tout cela est tiré du trésor social].

453 Pierre Bourdieu, The Forms of Capital, in Handbook for Theory and Research for the Sociology of Education, ed. John G. Richardson (Westport: Greenwood, 1986), 241-258. Seoyong Kim, Hyesun Kim, "Does Cultural Capital Matter? Cultural Divide and Quality of Life," Social Indicators Research 93 (2009), 296-297.

454 Philosophie sociale, 214.

455 See above, 4. 3. 
The second component of Moses Dobruska's thought is its social-philosophical side. Thisdiffers from the avowedly scientific approach, which I have termed sociological, in its evaluative and normative-ethical dimension. It is a goal- and targetoriented philosophy. Indeed, Moses Dobruska evaluates and criticizes the social order of the Ancien Régime and diagnoses all of the social and political dysfunctions that were responsible for the collapse of feudalistic society. Moreover, with his Universal Constitution he gives clear indications about the ethical principles, social institutions, and norms that must permeate a new democratic society. Finally, Moses Dobruska addresses his work to specific social actors: to all the men of thought (hommes qui pensent et, qui jugent par eux-mêmes), who are seeking the truth, and to the French people. Led by his Philosophie sociale they will engage in transformative action towards the existing social reality.

After completing this long journey into the social thought of Dobruska, in the seventh chapter I demonstrated the depth of the reception and influence of the Philosophie sociale. I believe that the results of this investigation are new and important. Step by step, I have recorded the texts which, without mentioning it, most likely take up ideas expressed for the first time by Dobruska. The catalogue is amazing. They range from the provisional Constitution of December 4, 1793, whose extender, Jacques-Nicolas Billaud-Varenne, treasures the Philosophie sociale, ${ }^{456}$ to the works of two great masters of French social thought, Henri de Saint-Simon and Auguste Comte. ${ }^{457}$ Textual and philological comparison allows us to follow the echoes of cultural and social disorganization/reorganization, so characteristically theorized by Dobruska, first in Saint-Simon and then in Comte. But the loans from the Philosophie sociale don't stop there. The famous Comtian law of the three stages also has its direct precedent in Dobruska, as I think I have demonstrated in a philologically clear manner.

In this way, a hitherto underestimated bond is reconstructed, linking the sociology-in-progress of Montesquieu - which Raymond Aron rightly considered the first exponent of the discipline, if not in name, in its cognitive intentions - to that of Auguste Comte, already formed and self-aware. Between the former and the latter, both rightly considered leading exponents of European thought, our Moses Dobruska, an outsider by origin and by tormented biographical fate, has carved out a distinguished intellectual role.

456 See above, 7.1.2.

457 See above, 7. 2. and 7. 3. 
